\title{
Influence of enriched soaking water on shiitake (Lentinus edodes (Berk.) Singer) mushroom yield and properties
}

\author{
Mohammad-Ebrahim RANJBAR ${ }^{1}$, Jamal-Ali OLFATI ${ }^{2 *}$ and Masoumeh AMANI ${ }^{3}$
}

Received July 22, 2017; accepted November 06, 2017.

Delo je prispelo 22. julija 2017, sprejeto 06. novembra 2017.

\begin{abstract}
Shiitake is an edible mushroom native to East Asia. In the present research, the soaking water was targeted as the vehicle to enrich the substrate. The amount of nutrients in the substrate is severely reduced by mycelium growth and development during spawn running and browning period. Some part of this reduction can be compensated by soaking the substrate in the enriched soaking water. In this study, soaking water was enriched by some complement materials and enrichment effects on some important properties of shiitake mushroom were evaluated. The highest biological efficiency $(69.88 \%)$ was gained with soaking the blocks in wheat bran extraction suspension. The highest dry matter of mushroom was obtained by rice bran extraction suspension as the enriched soaking water. The results of this research showed that some important properties of shiitake mushroom can be improved by soaking the blocks with enriched soaking water. According to the results, wheat bran extraction suspension was the best enriched solution to increase productivity of shiitake mushrooms and rice bran extraction suspension was suitable to improve quality of mushrooms.
\end{abstract}

Key words: biological efficiency; dry matter; soaking water; shiitake mushroom; wheat bran

\section{IZVLEČEK}

\section{VPLIV OBOGATENE VODE ZA OMOČENJE SUBSTRATA NA PRIDELEK IN LASTNOSTI ŠITAK (Lentinus edodes (Berk.) Singer)}

Šitaka je užitna goba, avtohtona v vzhodni Aziji. V raziskavi je bila preučevana tekočina za namakanje substrata kot sredstvo za njegovo obogatitev. Količina hranil v substratu se močno zmanjša med rastjo in razvojem micelija od inokuluma do faze porjavenja. Nekaj od tega zmanjšanja bi lahko nadomestili $\mathrm{z}$ namakanjem substrata $\mathrm{v}$ vodi, obogateni $\mathrm{s}$ hranili. V raziskavi je bila tekočina za namakanje substrata obogatena $\mathrm{z}$ nekaterimi dopolnimi snovmi, učinki tega obogatenja so bili ovrednoteni na osnovi nekaterih pomembnih lastnosti gob. Največja biološka učinkovitost $(69,88 \%)$ je bila pridobljena, če so bili bloki substrata namočeni $\mathrm{v}$ suspenziji vode $\mathrm{z}$ otrobi pšenice. Največ suhe snovi so imele gobe, kadar je bil substrat namočen s suspenzijo riževih otrobov. Izsledki te raziskave kažejo, da bi lahko nekatere pomembne lastnosti šitak izboljšali $Z$ namakanjem blokov substrata $\mathrm{v}$ vodi obogateni $\mathrm{s}$ hranili. Glede na rezultate je bila suspezija pšeničnih otrobov najboljša za povečanje produktivnosti šitak, suspenzija riževih otrobov pa za izboljšanje kvalitete gob.

Ključne besede: biološka učinkovitost; suha snov; voda za namakanje; gobe šitake; pšenični otrobi

\section{INTRODUCTION}

Shiitake (Lentinus edodes (Berk.) Singer) is an edible mushroom native to East Asia (Chang \& Miles, 2004). Shiitake is one of the most popular edible mushrooms and the second most cultivated mushroom in the world (Ivan et al., 2003, Royse \& Sanchez, 2007). Shiitake mushrooms have excellent nutritional value.
Their raw fruit bodies contain water, protein, lipids, carbohydrates as well as vitamins and minerals (Rahman \& Choudhury, 2012). Shiitake is traditionally cultivated on tree logs, which have been partly replaced by bag cultivation by using sterilized sawdust to enhance the biological efficiency and to reduce duration

1 PhD student, Department of Horticultural sciences, Faculty of Agricultural sciences, University of Zanjan. Zanjan, Iran, I.R.

2 Assistant professor, Department of Horticultural sciences, Faculty of Agricultural sciences, University of Guilan. Rasht, Iran, I.R. *corresponding author: jamalaliolfati@gmail.com

3 Former master science student, Department of Horticultural sciences, Faculty of Agricultural sciences, University of Guilan. Rasht, Iran. I.R. 
of production cycle (Mata \& Hernandez, 2004). Soaking or physical shock is a process, which is used to convert primordia into fruiting body of mushroom. Soaking blocks in cold water is the most typical means to induce fruiting body formation in shiitake mushroom cultivation (Chang \& Miles, 2004, Mata \& Hernandez, 2004).

The amount of nutrients in the substrate is severely reduced by mycelium growth and development during spawn running and browning period. Some part of this reduction can be compensated by soaking the substrate in enriched soaking water (Sabota et al., 2004). Soaking water can be enriched by many different organic or chemical supplement materials such as: urea, sucrose, bran, cereals flour and beet molasses (Boyle, 1998, Sabota et al., 2004). Enriched soaking water can be used to improve some important properties of shiitake mushrooms such as: biological efficiency and number of fruiting bodies (Sabota et al., 2004). The general purpose of the current study was to evaluate the effect of enriched soaking water on some important properties of shiitake mushrooms. All supplement materials used in this research were natural, and we did not use any chemical materials to enrich the soaking water.

\section{MATERIALS AND METHODS}

The experiment was carried out at a commercial mushroom farm, Babolsar, Iran, between April and September 2016. Wheat straw and wheat bran were used as lignocelluloses substrate and supplemental material, respectively (Ranjbar \& Olfati, 2017). We had two experiments in this study:

\subsection{First experiment}

On first experiment, we evaluated suitable concentration of enriched soaking water to soak the blocks. We tested a wide range of concentration of enriched soaking water from low to high concentration. According to the results, high concentration of enriched soaking water can cause fungal contamination in the harvest period (especially Trichoderma spp.). Based on our results, fungal contamination will decrease by reducing of enriched soaking water concentration; thus low concentration of enriched soaking water was used in this experiment.

\subsection{Second experiment}

On second experiment, we evaluated the effect of quality of enriched soaking water on some important properties of shiitake mushroom. In this experiment, soaking water was enriched by organic and accessible materials such as wheat bran, rice bran, corn flour and soy bean flour, and the effects of enriched soaking water on some important properties of shiitake mushrooms were evaluated.

The experiment was carried out in this way:

\subsubsection{Spawn preparation}

Medium of mother culture was prepared by mixing sawdust and wheat bran at 2:1 ratio and $0.2 \% \mathrm{CaCO}_{3}$, and the moisture content was maintained at $65 \% .250 \mathrm{~g}$ of the mixture was filled in the polypropylene bags. The packets were sterilized in an autoclave for $1 \mathrm{~h}$ at $120^{\circ} \mathrm{C}$ under $1 \mathrm{~kg} / \mathrm{cm}^{2}$ pressure. After cooling, the packets were inoculated with the pure culture of WW77 strain. The inoculated packets were incubated at $22 \pm 2{ }^{\circ} \mathrm{C}$ for. The fully colonized packets were used for spawning.

\subsubsection{Substrate preparation and spawning}

The substrate components $(11 \%$ wheat straw approximate moisture content and 40-50\% estimated wheat bran moisture content) were dried for 4 to 5 days fully exposed outdoors. Each substrate was supplemented with $30 \%$ wheat bran. One-percent calcium carbonate and one-percent sugar were added to all bags. Water was added to raise the moisture content of the substrate to approximately $60 \%$. Polypropylene bags $(22.5 \times 30 \mathrm{~cm})$ were filled with $1 \mathrm{~kg}$ of substrate, sterilized once at $121^{\circ} \mathrm{C}$ and $1.5 \mathrm{kgcm}^{-2}$ pressure for $1 \mathrm{~h}$ and for several hours allowed to cool down to the needed inoculation temperature.

Substrate bags were opened and the spawn (5\% w/w) was placed into each bag at the near center using a sterilized metal instrument. After spawning, the substrates were incubated at $25-28{ }^{\circ} \mathrm{C}$ in the dark condition and $70 \%$ relative air humidity. After 60 to 90 days, bags were removed to expose the surface of the blocks to fluorescent light $(12 \mathrm{~h} / \mathrm{d})$ for 20 to 30 days. After bag removal, a hard and thick brown coat formed on the surface of the block. During this phase, environmental humidity was raised to $90-95 \%$ to prevent water loss from the blocks.

\subsubsection{Preparation of enriched soaking water}

The blocks were soaked in enriched soaking water in a tank for 12 hours. Soaking water suspension was produced with wheat bran, rice bran, corn flour and soybean flour. For preparing each one of these treatments, $1.5 \mathrm{~kg}$ of the complement material was added to 15 liters of water and boiled for about 2 hours. After cooking suspension was filtered through $8 \mu \mathrm{m}$ filter and brought into 20 liters volume by tap water. 


\subsubsection{Harvesting and statistical analysis}

After soaking, all blocks were placed in a fruiting room with a controlled temperature of 16 to $18{ }^{\circ} \mathrm{C}$ and relative humidity between 90 and $95 \%$. Mushrooms were harvested from the substrates at the same time each day, when the veil had broken and the gills were fully exposed (Royse \& Sanchez, 2007). The mushrooms were then weighed. At the end of the harvest period (60 days), the accumulated data were used to calculate biological efficiency. The experiment was arranged in a completely randomized design with 5 treatments replicated 4 times, and the results were analyzed using the Minitab 16 software and means were compared using Tokay's test (HSD) $(P \leq 0.05)$.

\section{RESULTS AND DISCUSSION}

Table 1 shows nutritional composition of the complement materials.

Table 1: Proximate content complement material (100 g) (Barikmo et al., 2004)

\begin{tabular}{|l|c|c|c|c|c|c|}
\hline $\begin{array}{l}\text { Enrichment } \\
\text { material }\end{array}$ & $\begin{array}{c}\text { Protein } \\
(\mathrm{g})\end{array}$ & $\begin{array}{c}\text { Carbohydrates } \\
(\mathrm{g})\end{array}$ & $\begin{array}{c}\mathrm{K} \\
(\mathrm{mg})\end{array}$ & $\begin{array}{c}\mathrm{Ca} \\
(\mathrm{mg})\end{array}$ & $\begin{array}{c}\mathrm{Mg} \\
(\mathrm{mg})\end{array}$ & $\begin{array}{c}\mathrm{P} \\
(\mathrm{mg})\end{array}$ \\
\hline Wheat bran & 15.55 & 49.62 & 1182 & 73 & 611 & 1013 \\
\hline Rice bran & 13.38 & 65.02 & 1457 & 57.03 & 25.12 & 1677.12 \\
\hline Corn flour & 7.8 & 83 & 1468 & 42.43 & 105 & 259 \\
\hline Soybean flour & 14.31 & 17.08 & 443.30 & 17.42 & 73.46 & 210.09 \\
\hline
\end{tabular}

According to Table 2, biological efficiency, protein and nitrogen content, yield and dry matter are affected by the quality of soaking water.

Table 2: ANOVA table effect of soaking water suspension on measured traits

\begin{tabular}{|l|c|c|c|c|c|c|c|c|}
\hline \multirow{2}{*}{ Source } & \multirow{2}{*}{ d.f. } & \multicolumn{7}{|c|}{ Mean square } \\
\cline { 3 - 9 } & & $\begin{array}{c}\text { Biological } \\
\text { efficiency }\end{array}$ & Yield & $\begin{array}{c}\text { Dry } \\
\text { matter }\end{array}$ & Protein & $\begin{array}{c}\text { Fruit body } \\
\text { mass }\end{array}$ & $\begin{array}{c}\text { Diameter } \\
\text { of cap }\end{array}$ & Nitrogen \\
\hline $\begin{array}{l}\text { Soaking water } \\
\text { suspension }\end{array}$ & 4 & $18.998^{* *}$ & $4876.2^{* *}$ & $12.420^{* *}$ & $8.365^{* *}$ & $1.720^{\text {ns }}$ & $0.615^{\text {ns }}$ & $3.495^{* *}$ \\
\hline Error & 15 & 1.567 & 64.2 & 0.667 & 0.712 & 0.576 & 0.682 & 0.466 \\
\hline C.V. (\%) & & 2.88 & 2.01 & 3.12 & 6.21 & 3.62 & 13.86 & 18.16 \\
\hline
\end{tabular}

ns, **, * not significant or significant at $P \leq 0.05$ and $P \leq 0.01$, respectively

\subsection{Biological efficiency}

The highest biological efficiency $(69.88 \%)$ was recorded when the substrates were soaked in wheat bran extraction suspension (Table 3). According to Moonmoon et al. (2011), the increased productivity of shiitake mushrooms supplemented with wheat bran can be attributed to the carbohydrates, amino acids and mineral elements present in this supplement. Mineral materials are generally considered as the most important factor to influence primordia development and fruiting body formation (Haeng et al., 2005), the amount of nutrients in soaking water will be increased by addition of wheat bran extract to the soaking water; thereby wheat bran extraction suspension can be used to improve the biological efficiency in shiitake mushrooms cultivation. Organic sources of nitrogen can be easily used by mushrooms and wheat bran is considered as one of the most important organic sources of nitrogen in mushroom cultivation (Nones et al., 2012). 
M.E. RANJBAR et al.

Table 3: Effect of soaking water suspensions on some properties of shiitake mushroom

\begin{tabular}{|l|r|r|r|r|r|r|r|}
\hline $\begin{array}{l}\text { Enrichment } \\
\text { material }\end{array}$ & $\begin{array}{c}\text { Biological } \\
\text { efficiency } \\
(\%)\end{array}$ & \multicolumn{1}{|c|}{$\begin{array}{c}\text { Yield } \\
(\mathrm{g} / \mathrm{log})\end{array}$} & $\begin{array}{c}\text { Dry } \\
\text { matter } \\
(\%)\end{array}$ & $\begin{array}{c}\text { Protein } \\
(\%)\end{array}$ & $\begin{array}{c}\text { Fruit body } \\
\text { mass } \\
(\mathrm{g})\end{array}$ & $\begin{array}{c}\text { Diameter of } \\
\text { cap } \\
(\mathrm{cm})\end{array}$ & \multicolumn{1}{c|}{$\begin{array}{c}\text { Nitrogen } \\
(\%)\end{array}$} \\
\hline Wheat bran & $69.88 \mathrm{a}$ & $1084.26 \mathrm{a}$ & $26.52 \mathrm{ab}$ & $15.84 \mathrm{a}$ & $45.63 \mathrm{a}$ & $5.32 \mathrm{a}$ & $3.98 \mathrm{a}$ \\
\hline Rice bran & $64.84 \mathrm{~b}$ & $1006.06 \mathrm{~b}$ & $28.20 \mathrm{a}$ & $15.31 \mathrm{a}$ & $46.12 \mathrm{a}$ & $5.92 \mathrm{a}$ & $3.79 \mathrm{a}$ \\
\hline Corn flour & $66.02 \mathrm{~b}$ & $1014.37 \mathrm{~b}$ & $26.31 \mathrm{~b}$ & $12.41 \mathrm{~b}$ & $47.11 \mathrm{a}$ & $6.38 \mathrm{a}$ & $2.13 \mathrm{~b}$ \\
\hline Soybean flour & $66.00 \mathrm{~b}$ & $1012.43 \mathrm{~b}$ & $25.81 \mathrm{~b}$ & $14.92 \mathrm{a}$ & $46.92 \mathrm{a}$ & $6.01 \mathrm{a}$ & $3.80 \mathrm{a}$ \\
\hline Control & $64.32 \mathrm{~b}$ & $997.50 \mathrm{~b}$ & $23.32 \mathrm{c}$ & $12.29 \mathrm{~b}$ & $47.04 \mathrm{a}$ & $6.12 \mathrm{a}$ & $2.11 \mathrm{~b}$ \\
\hline
\end{tabular}

a values in columns followed by the same letter are not significantly different, $P \leq 0.01$, Tukey's (HSD) test.

\subsection{Yield}

The highest yield per log was obtained when the substrates were soaked in wheat bran extraction suspension. Wheat bran contains high amounts of protein and some mineral materials (Barikmo et al., 2004), which improves growth, development and quality of mushrooms. Yield increased 7.3, 6.5, 6.7 and $8 \%$ in wheat bran extraction suspension compared to rice bran extraction suspension, corn flour extraction suspension, soy bean flour extraction suspension and control, respectively. Our results showed that productivity of shiitake mushrooms increased with use of enriched soaking water in cultivation process, but this change is not substantial. According to Sabota et al. (2004), yield per log increased (12\%) with addition of urea to soaking water (2400 $\mathrm{ppm}$ ) compared to control. This indicates that the use of chemical materials to enrich the soaking water can have greater effect on increasing the production of shiitake mushrooms compared to organic materials, but organic mushrooms will not be produced by employment of chemical materials in enriching of soaking water.

\subsection{Dry matter}

The highest fruiting bodies dry matter was recorded when the substrates were soaked in rice bran extraction suspension. Dry matter increased $5.96 \%$ in rice bran extraction suspension compared to wheat bran extraction suspension. The addition of organic enrichment materials to the soaking water increased dry matter to average $12.73 \%$ over the control, this increase is explained by the fact that organic enrichment materials are a source of energy and carbon which, according to Rossi et al. (2003), are important for the metabolic activity of the mushrooms. Our results showed that enriching soaking water by organic materials can have impressive effect on improvement of dry matter of shiitake mushrooms.

\subsection{Protein and nitrogen}

Maximum protein content of mushroom $(15.84 \%)$ was achieved by wheat bran extraction suspension. The lowest protein content of mushroom $(12.29 \%)$ was observed when the substrates were soaked in control soaking water. The highest nitrogen content of mushroom $(3.98 \%)$ was recorded with wheat bran extraction suspension as the enriched soaking water.

Protein content of mushrooms is significantly enhanced by using of enrichment materials in soaking water. The difference in protein content of mushrooms can be explained by variety of nitrogen content in different enriched soaking water. Wang et al. (2001) reported that nitrogen is essential for synthesis of protein in mushrooms and protein content of edible mushroom is influenced by species and the quality of growing substrate.

\subsection{Fruit body mass and diameter of cap}

There were no significant differences in fruit body mass and diameter of cap among the blocks soaked in different enriched soaking water types. Increasing biological efficiency by addition of enrichment materials to the soaking water can be explained by an increase in the number of fruit bodies in this experiment. The results of this study are similar to Oei \& Nieuwenhuizen (2005), they reported that primordia formation, primordia development and number of shiitake fruiting bodies increased with use of organic enrichment materials such as bran, cereals flour and beet molasses. 


\section{CONCLUSION}

In the present study different organic materials were used to enrich the substrate soaking water in shiitake mushroom cultivation. Results showed enrichment of soaking water with organic materials such as wheat bran, rice bran and soybean flour is effective on some of important properties of shiitake mushroom and can be proposed as the new and effective alternative for chemical enrichment of soaking water. According to the results, wheat bran extraction suspension was the best enriched suspension to increase productivity of shiitake mushroom and rice bran extraction suspension was suitable to improve the quality of mushroom. Our results showed that corn flour is not suitable to enrich the soaking water in shiitake mushroom cultivation.

\section{REFERENCES}

Barikmo I, Ouattara F, Oshaug A. (2004). Protein, carbohydrate and fibre in cereals from Mali-how to fit the results in a food composition table and data base. Food Composition Analysis, 17, 291-300. doi:10.1016/j.jfca.2004.02.008

Boyle D. (1998). Nutritional factors limiting the growth of Lentinus edodes and other white-rot fungi in wood. Soil Biology and Biochemistry, 30, 817-823. doi:10.1016/S0038-0717(97)00159-4

Chang ST, Miles PG. (2004). Mushrooms: Cultivation, nutritional value, medicinal effect, and environmental impact, Vol. 2. CRC Press, Boca Raton. doi:10.1201/9780203492086

Haeng B, Pyungchang D, Jongno G. (2005). Mushroom grower handbook. $2^{\text {th }}$ Eds. The mush word press. Korea.

Ivan HR, Antonio CM, Jose OM, Jose CB. (2003). Supplementation of sugarcane bagasse with rice bran and sugarcane molasses for shiitake (Lentinula edodes) spawn production. Brazil Journal of Microbiology, 34, 61-65. doi:10.1590/S151783822003000100013

Mata G, Hernandez R. (2004). Cultivation of the edible mushroom Lentinula edodes in pasteurized wheat straw - alternative use of georthermal energy in Mexico. Enginering in Life Sciences, 4, 363-367. doi:10.1002/elsc.200420042

Mckevith B. (2004). Nutritional aspects of cereals. British Nutrition Bulletin, 29, 111-142. doi:10.1111/j.1467-3010.2004.00418.x

Moonmoon M, Shelly NJ, Asaduzzaman M, Uddin N, Hossain K, Tania M, Ahmed S. (2011). Effects of different levels of wheat bran, rice bran and maize powder supplementation with saw dust on the production of shiitake mushroom (Lentinus edodes (Berk.) Singer). Saudi Journal of Biological Sciences, 18(4), 323-328. doi:10.1016/j.sjbs.2010.12.008

Nunes MD, Luz GM, Paes SA, Ribeiro JO, Silva M, Kasuya MC. (2012). Nitrogen supplementation on the productivity and the chemical composition of oyster mushroom. Journal of Food Research, 2, 113-119. doi:10.5539/jfr.v1n2p113

Oei., P. and Nieuwenhuizen, B. (2005). Small-scale mushroom Cultivation. Digigrafi, Wageningen, the Netherlands.

Rahman T, Chowdhury M. (2012). Shiitake mushroom: a tool of medicine. Bangladesh Journal of Medicin Biochemistry, 5, 24-32.

Ranjbar ME, Olfati JA. (2017). Evaluation of substrate components on shiitake mushroom properties. International Journal of Vegetable Sciences, 23, 145-150. doi:10.1080/19315260.2016.1220438

Rossi IH, Monteiro AC, Machado JO, Andrioli JL, Barbosa JC. (2003). Shiitake (Lentinula edodes) production on a sterilized begasse substrate enriched with rice bran and sugarcane molasses. Brazilian Journal of Microbiology, 34, 66-71.

Royse DJ, Sanchez JE. (2007). Ground wheat straw as a substitute for portions of oak wood chips used in shiitake (Lentinula edodes) substrate formulae. Bioresource Technology, 98, 2137-2141. doi:10.1016/j.biortech.2006.08.023

Royse DJ, Rhodes TW, Sanchez JE. (2002). Vacuumsoaking of wood chip shiitake (Lentinula edodes) logs to reduce soak time and log weight variability and to stimulate mushroom yield. Appllied Microbiology and Biotechnology, 58, 58-62. doi:10.1007/s00253-001-0870-y

Royse DJ, Bahler BD, Bahler CC. (1990). Enhanced yield of shiitake by saccharide amendment of the synthetic substrate. Appllied Environmental Microbiology, 56, 479-482.

Sabota C, Bell C, Ghale G. (2004). Does amendment of soak solution with sucrose and urea increase production of shiitake mushrooms on sawdust blocks? Hort Technology, 14, 393-397. 
M.E. RANJBAR et al.

Wang D, Sakoda A, Suzuki M. (2001). Biological efficiency and nutritional value of Pleurotus ostreatus on spent

beer grain. Bioresource Technology, 78, 293-300. doi:10.1016/S0960-8524(01)00002-5 